\title{
Influence of Non-Confinement Rearing under High Infectious Pressure from Mycoplasma hyopneumoniae: Pig Performance, Acute Phase Proteins and Cortisol Assessment
}

\author{
S. P. FRANEK, G. BILKEI \\ Bilkei Consulting, Dübendorf, Switzerland \\ Received November 3, 2003 \\ Accepted July 29, 2004 \\ Abstract
}

Franek S.P., G. Bilkei: Influence of Non-confinement Rearing under High Infectious Pressure from Mycoplasma hyopneumoniae: Pig Performance, Acute Phase Proteins and Cortisol Assessment. Acta Vet. Brno 2004, 73: 335-340.

The objective of this study was to evaluate serum concentrations of acute phase proteins (APP), haptoglobin (HPT), alpha 1-acid glycoproteins (AGP) and cortisol in indoor or outdoor raised pigs over time and under high pressure of Mycoplasma hyopneumoniae, and to determine whether changes in APPs were associated with pig performance. Two groups of 10 pigs each were raised indoors from weaning to slaughter (group 1), and two groups of 10 pigs each of same age and health status were raised outdoors (group 2). Serum samples were taken from each pig at weaning (at day 21 of lactation), at day 60,90,120 and 150 days of age. Production data (average daily gain, ADG, feed conversion ratio, FC), seropositivity to $M$. hyopneumoniae, HPT, AGP and cortisol were evaluated.

In indoor raised pigs HPT persistently increased, in outdoor raised ones a sharp increase occurred after a cold weather period. AGP was negatively correlated with body weight, indicating that an activation of cellular immune response negatively effects growth rate of the growing finishing pigs.

Pig, outdoor, stress, acute phase proteins, cortisol, Mycoplasma hyopneumoniae, average daily gain, feed conversion ratio

The commercial swine industry in Europe is characterised by fierce competition to improve production efficiencies while maintaining the political requirements of the consumer and fulfilling the ethological requirements of the producing animals. There are five main factors that influence pig's growth performance: genetic, gender, nutrient intake, growing environment and infections pressure (Bilkei 1996).

Outdoor pig production lives its renaissance in Europe. Nevertheless, stressful outdoor pig raising may be accompanied with low production levels, unsatisfactory immune response to infectious agents and detrimental health status (Docic and Bilkei 2001). Potential factors limiting growth in outdoor production include physical, social and microbial conditions that may contribute to physiological and immunological stress (Bilkei 1996). The possibility of monitoring a pig's response to its environment with physiological markers is intriguing.

Acute phase proteins (APP) include a group of liver synthesized proteins the concentration of which in serum varies in response to infections, stress and inflammatory processes (Burger et al. 1992). APP function to restore biologic homeostasis when it is disrupted by injury, neoplastic disease or infection, and they are thought to be sensitive but non-specific physiologic markers of stress. They have been proposed as indicators of pig performance and the impact of such specific production practices as outdoor raising (Bilkei 1996).

The most frequently studied serum APPs in swine are haptoglobin (HPT), alpha 1-acid glycoproteins (AGP), and C-reactive protein (CRP) (Hall et al. 1992; Eurell et al. 1992). More than 30 APPs have been identified (Grellner et al. 2002). Changes in APP can be used to monitor systemic response to physiological insults (Hall et al. 1992) and weight 
gain in pigs (Eurell et al. 1992). HPT and AGP have the potential as indicators of clinical or subclinical disease or stress (Eckersall et al. 1996). A study demonstrated that APPs rise in pigs in response to cytokines (Hall et al. 1992).

Evaluating a particular APP might provide information about the health status in a pig unit (It oh et al. 1993). Serum concentrations of APP may decrease or increase in response to the same stimulus (Horadagoda et al. 1999). High AGP levels may negatively influence the pharmacological effects of antimicrobial drugs (S on et al. 1996).

The objective of the present study was to evaluate serum concentrations of APP (AGP, HPG) and cortisol over time in indoor or outdoor raised pigs under high infectious pressure of M. hyopneumoniae (MH) and to determine, whether changes in these APPs or cortisol were associated with health status and performance in pigs.

\section{Materials and Methods}

The trial was performed in a large Croatian pig production unit with high prevalence of porcine respiratory disease complex (PRDC) and high infectious pressure of MH (fattening mortality $11.2 \pm 2.9 \%$ during 1993-2003; $7.1 \pm 1.3 \%$ due to $\mathrm{MH}$ ), from March 2003 to October 2003. Actinobacillus pleuropneumoniae, swine influenza virus, Haemophilus parasuis, Ascaris suis infections have been sporadically found by postmortem examination and laboratory diagnosis in this unit, causing $0.7 \pm 0.03 \%$ of fattening mortality.

Forty castrated, healthy male weaned piglets (weaned in litters of 10 piglets, from sows of parity 3 , and sow body condition score of 3 [scored according to Bilkei et al. 1995], weaned at 21 days of lactation) of similar weights were selected. All pigs were individually weighed at weaning on an electronic digital scale and identified with ear tags. Four randomised (computer-generated list within blocks of similar weights in a 1:1 assignment ratio) parallel treatment groups (two indoor groups $\mathrm{n}=10$ per group, $5.9 \pm 0.3 \mathrm{~kg}$, and two outdoor groups, $5.8 \pm 0.2 \mathrm{~kg}, \mathrm{n}=10$ per group) of piglets were formed. The indoor pigs were raised in wire-mesh floor pens $\left(0.9 \mathrm{~m}^{2}\right.$ per pig). The pen contained 2 self-feeders and 2 nipple drinkers. The room had a shallow-pit manure-storage system and was environmentally controlled with temperature maintained continuously at 22 to $24{ }^{\circ} \mathrm{C}$, air speed of $0.2 \mathrm{~m} \cdot \mathrm{sec}^{-1}$ and a relative humidity of $75 \%$. Outdoor pigs were raised in huts on deep straw bedding and had access to a meadow of $10 \mathrm{~m}^{2}$ per pig. The animals received identical diets throughout the study and were treated by the same care taker. The pigs received no prophylactic medication. No pigs died during the study.

Sampling procedure

In order to evaluate serum titer changes of Mycoplasma hyopneumoniae (MH) and to monitor changes in concentrations of serum HTP, AGP and cortisol, serum samples were taken from each pig at weaning (at day 21 of lactation), at day 60,90,120 and 150 days of age. Attention was paid to the blood sampling. Since cortisol is a stress hormone, stress-free sampling was performed by jugular vein puncture in individual cages in a separate room (no hog snare used at weaning, soft, thick rope-hog-snare was used for animals of 60, 90, 120 and 150 days of age). The selected pigs were tested for each parameter at each data point.

The presence of antibody to MH using Tween 20 ELISA $^{\circledR}$ was tested according to Bereiter et al. (1990) and Nicolet et al. (1980): $\mathrm{MH}$ was grown in Friis medium at $35{ }^{\circ} \mathrm{C}$. Cells were pelleted by centrifugation at $10000 \mathrm{rpm}$ for $30 \mathrm{~min}$. The pellet was washed three times and suspended in phosphate buffered saline (PBS, pH 7.2). The suspension was mixed with an equal volume of $2 \%$ Tween-20 in PBS, stirred 90 min at $37^{\circ} \mathrm{C}$, and centrifuged at $10000 \mathrm{rpm}$ for 1 hour. Supernatant was then passed through a $0.2 \mu \mathrm{m}$ membrane filter and stored at $-70{ }^{\circ} \mathrm{C}$ in aliquots. For ELISA, 96-well microplates were coated by incubating a 4 ${ }^{\circ} \mathrm{C}$ overnight with $100 \mu \mathrm{l}$ of antigen in pH 9.6 carbonate/bicarbonate buffer. Antigen was removed and plates were incubated at $37^{\circ} \mathrm{C}$ for $3 \mathrm{~h}$ with blocking solution containing $1 \%$ bovine serum albumin (BSA) and $3 \%$ rabbit serum in PBS. Before use, the plates were washed three times with PBS $0.05 \%$ Tween-20. Fifty $\mu 1$ of each test serum diluted 1:50 in blocking solution was added to duplicate wells. Plates were incubated at 37 ${ }^{\circ} \mathrm{C}$ for $30 \mathrm{~min}$. After washing, $50 \mu \mathrm{l}$ of peroxidase-conjugated rabbit anti-swine IgG were added to each well and incubated at $37{ }^{\circ} \mathrm{C}$ for $30 \mathrm{~min}$. Wells were washed again, and $50 \mu \mathrm{l}$ of substrate containing o-phenylenediamine was added. After $10 \mathrm{~min}$ at room temperature, the reaction was stopped by adding $50 \mu 10.5 \mathrm{~N}$ sulphuric acid.

Average daily gain (ADG), feed conversion ratio (FC) were calculated.

ESAP (line 89, Exposure Serum Antibody Profiles, Biovet, Quebec, Canada) was used to analyze titer changes. Serum inhibition test was used for MH seropositivity and for the purpose of this trial, $>50 \%$ was considered positive. Assays for ELISA serum AGP and HPT were performed according to ESAP, and cortisol concentrations were determined using a commercial kit (Diagnostic Co, LA, CA, USA). The minimum detectable cortisol level was 2 ng per ml, with a within-assay coefficient variation of $4.2 \%$.

Statistical analysis 
For statistical analysis, the individual pig was the experimental unit. Upon selection pigs were ranked by weight and assigned to treatments within blocks. Data were analyzed using ANOVA (General Linear Model [GML], SAS, Cary, North Carolina, USA 1990) for repeated measurements. Between-group comparisons between indoor and outdoor raised pigs, at specific time points were made according to unpaired $t$-test, while within-group comparisons between two data collection points were made according to paired $t$-test. Correlation coefficients (r) were reported on the overall means for each variable for indoor and outdoor pigs, using Fishers's $r$ to $\mathrm{z}$ analysis to describe linear relationships between two variables within the same group. Variables used for correlation comparisons were body weight, MH titers and serum concentrations of cortisol, AGP and HPT. Correlation comparisons were made between parameters of interest, and the positive or negative change in the linear relationship of the parameters compared over the same time period were reported. In all comparisons, values $P<0.05$ were considered significant.

\section{Results}

No significant differences $(P=0.9)$ were found at weaning in $\mathrm{MH}$ titers. Between weaning and $60 \mathrm{~d}$ of age, mean $\mathrm{MH}$ titer decreased $(P<0.01)$ in the outdoor groups and increased $(P<0.001)$ in the indoor group of pigs (Table 1$)$. Between 60 and $90 \mathrm{~d}$ of age, mean $\mathrm{MH}$ titer increased $(P<0.001)$ in the outdoor animals and decreased in the indoor pigs $(P<0.01)$. Between 90 and $120 \mathrm{~d}$ of age, mean $\mathrm{MH}$ titer decreased in the outdoor group $(P<0.001)$, while increasing in indoor animals $(P<0.001)$. The maximum number of $\mathrm{MH}$ positive results was observed at $90 \mathrm{~d}$ of age in the outdoor pigs and at $120 \mathrm{~d}$ of age in the indoor animals.

Table 1

Serum inhibition test for Mycoplasma hyopneumoniae in growing pigs under high infectious pressure of Mycoplasma hyopneumoniae in indoor and outdoor production

\begin{tabular}{|c|c|c|c|}
\hline Age of pigs & $\begin{array}{c}\text { Outdoor } \\
\% \pm \mathrm{SD}\end{array}$ & $\begin{array}{c}\text { Indoor } \\
\% \pm \mathrm{SD}\end{array}$ & $P$ value \\
\hline Weaning at 21 days of age & $0.47 \pm 0.1$ & $0.44 \pm 0.1$ & 0.9 \\
\hline Pigs of 60 d of age & $0.21 \pm 0.04$ & $27.19 \pm 5.5$ & $<0.001$ \\
\hline Pigs of $90 \mathrm{~d}$ of age & $22.48 \pm 2.9$ & $9.27 \pm 2.3$ & $<0.001$ \\
\hline Pigs of $120 \mathrm{~d}$ of age & $13.91 \pm 2.9$ & $78.1 \pm 14.1$ & $<0.001$ \\
\hline Pigs of $150 \mathrm{~d}$ of age & $11.71 \pm 2.8$ & $58.7 \pm 13.3$ & $<0.001$ \\
\hline
\end{tabular}

Table 2

Alpha 1-acid glycoproteins (AGP) serum values in growing pigs under high infectious pressure of $M$. hyopneumoniae in indoor and outdoor production

\begin{tabular}{|c|c|c|c|}
\hline Age of pigs & $\begin{array}{c}\text { Outdoor } \\
\mu \mathrm{g} \cdot \mathrm{ml}^{-1} \pm \mathrm{SD}\end{array}$ & $\begin{array}{c}\text { Indoor } \\
\mu \mathrm{g} \cdot \mathrm{ml}^{-1} \pm \mathrm{SD}\end{array}$ & $P$ value \\
\hline Weaning at 21 days of age & $769.4 \pm 102.1$ & $814 \pm 111.3$ & 0.70 \\
\hline Pigs of 60 d of age & $1122 \pm 121.4$ & $1176 \pm 103.6$ & 0.41 \\
\hline Pigs of 90 d of age & $867 \pm 112.1$ & $627 \pm 100.3$ & 0.001 \\
\hline Pigs of 120 d of age & $531 \pm 97.2$ & $518 \pm 114.7$ & 0.02 \\
\hline Pigs of 150 d of age & $427 \pm 92.8$ & $515 \pm 63.3$ & $<$ \\
\hline
\end{tabular}

Mean serum AGP concentrations differed $(P<0.03)$ between weaning and age of 60 $\mathrm{d}$ between the outdoor and indoor pigs. The highest AGP concentrations were found at an age of $60 \mathrm{~d}$ (Table 2$)$. Mean serum HPT increased $(P<0.02)$ both in outdoor and indoor pigs between weaning and $150 \mathrm{~d}$ of age. Maximum serum concentrations of HPT were observed at $90 \mathrm{~d}$ of age in indoor raised pigs (Table 3). Serum cortisol concentrations decreased $(P<0.001)$ between weaning and age of $60 \mathrm{~d}$ in the outdoor pigs, while increased $(P<0.001)$ in the indoor animals (Table 4). Between ages of 60 and $90 \mathrm{~d}$, serum concentrations of cortisol increased by $P<0.001$ in the outdoor group but revealed not changes in the indoor animals. Maximum serum concentrations of cortisol were found at an age of $90 \mathrm{~d}$ in the 
Table 3

Haptoglobin (HPT) serum values in growing pigs under high infectious pressure of $M$. hyopneumoniae in indoor and outdoor production

\begin{tabular}{|c|c|c|c|}
\hline Age of pigs & $\begin{array}{c}\text { Outdoor } \\
\mathrm{mg} \cdot \mathrm{dl}^{-1} \pm \mathrm{SD}\end{array}$ & $\begin{array}{c}\text { Indoor } \\
\mathrm{mg} \cdot \mathrm{dl}^{-1} \pm \mathrm{SD}\end{array}$ & $P$ value \\
\hline Weaning at 21 days of age & $1.89 \pm 0.2$ & $22.61 \pm 3.1$ & $<0.001$ \\
\hline Pigs of 60 d of age & $3.6 \pm 0.4$ & $21.27 \pm 3.1$ & $<0.001$ \\
\hline Pigs of 90 d of age & $40.83 \pm 5.1$ & $27.8 \pm 3.8$ & 0.04 \\
\hline Pigs of 120 d of age & $28.97 \pm 7.3$ & $30.85 \pm 5.0$ & 0.75 \\
\hline Pigs of 150 d of age & $34.87 \pm 4.9$ & $34.95 \pm 7.3$ & 0.98 \\
\hline
\end{tabular}

Table 4

Cortisol serum values in growing pigs under high infectious pressure of $M$. hyopneumoniae in indoor and outdoor production

\begin{tabular}{|c|c|c|c|}
\hline Age of pigs & $\begin{array}{c}\text { Outdoor } \\
\mathrm{gg} \cdot \mathrm{ml}^{-1} \pm \mathrm{SD}\end{array}$ & $\begin{array}{c}\text { Indoor } \\
\mu \mathrm{g} \cdot \mathrm{ml}^{-1} \pm \mathrm{SD}\end{array}$ & $P$ value \\
\hline Weaning at 21 days of age & $1.88 \pm 0.3$ & $1.28 \pm 0.1$ & 0.04 \\
\hline Pigs of $60 \mathrm{~d}$ of age & $0.9 \pm 0.4$ & $2.63 \pm 3.3$ & $<0.001$ \\
\hline Pigs of $90 \mathrm{~d}$ of age & $2.66 \pm 0.4$ & $2.88 \pm 0.8$ & $<2$ \\
\hline Pigs of $120 \mathrm{~d}$ of age & $2.72 \pm 7.3$ & $1.75 \pm 5.0$ & $<0.001$ \\
\hline Pigs of $150 \mathrm{~d}$ of age & $1.93 \pm 0.4$ & $2.74 \pm 0.3$ & $<001$ \\
\hline
\end{tabular}

Table 5

Correlations between body weights, serum AGP, HPT, cortisol and serological titers against Mycoplasma hyopneumoniae under high infectious pressure of Mycoplasma hyopneumoniae in indoor and outdoor production

\begin{tabular}{|l|c|c|c|c|}
\hline \multirow{2}{*}{ Parameters compared } & \multicolumn{2}{c|}{ Outdoor pigs } & \multicolumn{2}{c|}{ Indoor pigs } \\
\cline { 2 - 5 } & Correlation & $P$ value & Correlation & $P$ value \\
\hline Weight $(\mathrm{kg}), \mathrm{AGP}\left(\mu \mathrm{g} \cdot \mathrm{ml}^{-1}\right)$ & -0.541 & $<0.0001$ & -0.476 & 0.0008 \\
\hline Weight $(\mathrm{kg}), \mathrm{HPT}\left(\mathrm{mg} \cdot \mathrm{dl}^{-1}\right)$ & 0.705 & $<0.0001$ & 0.280 & 0.602 \\
\hline Weight $(\mathrm{kg}), \mathrm{MH}$ titer & 0.782 & $<0.0001$ & 0.848 & $<0.0001$ \\
\hline Weight $(\mathrm{kg})$, cortisol $\left(\mu \mathrm{g} \cdot \mathrm{dl}^{-1}\right)$ & -0.014 & 0.9097 & 0.086 & 0.5654 \\
\hline AGP $\left(\mu \mathrm{g} \cdot \mathrm{ml}^{-1}\right), \mathrm{HPT}\left(\mathrm{mg} \cdot \mathrm{dl}^{-1}\right)$ & -0.342 & 0.084 & -0.224 & 0.1378 \\
\hline AGP $\left(\mu \mathrm{g} \cdot \mathrm{ml}^{-1}\right), \mathrm{MH}$ titer & -362 & 0.0055 & -0.324 & 0.0284 \\
\hline AGP $\left(\mu \mathrm{g} \cdot \mathrm{ml}^{-1}\right)$, cortisol $\left(\mu \mathrm{g} \cdot \mathrm{dl}^{-1}\right)$ & 0.269 & 0.433 & 0.105 & 0.4941 \\
\hline HPT $\left(\mathrm{mg} \cdot \mathrm{dl}^{-1}\right), \mathrm{MH}$ titer & 0.804 & $<0.0001$ & 0.044 & 0.7829 \\
\hline HPT $\left(\mathrm{mg} \cdot \mathrm{dl}^{-1}\right)$, cortisol $\left(\mu \mathrm{g} \cdot \mathrm{dl}^{-1}\right)$ & 0.115 & 0.3871 & 0.322 & 0.291 \\
\hline Cortisol $\left(\mu \mathrm{g} \cdot \mathrm{dl}^{-1}\right), \mathrm{MH}$ titer & 0.051 & 0.6878 & 0.111 & 0.4624 \\
\hline
\end{tabular}

indoor and at an age of $120 \mathrm{~d}$ in the outdoor animals. Correlations were found on the overall means for weight, acute phase proteins and serum cortisol (Table 5).

No significant differences were found in ADG and FC between the outdoor and indoor animals.

\section{Discussion}

In the present study it was our intention to quantify and document differences in immunological parameters between indoor or outdoor raised pigs under high infectious pressure of Mycoplasma hyopneumoniae.

According to Itoh et al. (1993) the upper normal limit of serum AGP is around $500 \mu \mathrm{g}$ per $\mathrm{ml}$ for young growing swine. Consistent with Itoh et al. (1993), in the present trial, serum AGP in both the outdoor and indoor animals tended to peak values at an age of $60 \mathrm{~d}$, 
and decayed after d 90. The cited authors (It oh et al. 1993) found that serum AGP increases in response to infections with $\mathrm{MH}$ in conventional raised pigs and concluded that a sudden increase in serum AGP may be associated with acute, rather than chronic infections. An increase in serum AGP concentrations may be considered as an indicator of intracellular immune communication, indicating an increase of cellular immune response (French 1989).

Consistent with It oh et al. (1993) and Grellner et al. (2002), in the present study, serum AGP concentrations did not increase with increasing MH titers.

In the present study, the negative correlation between AGP and weight gain, suggests that an active cellular immune response negatively influences growth rate of the growing pig. Itoh et al. (1993) suggested that in pigs chronically exposed to pathogens, both disease and stressors (as outdoor production in the present study) may contribute to increases in AGP.

The gradual increase in HPT serum concentrations in the present study is consistent with the findings of Grellner et al. (2002). The present findings indicate that these pigs were chronically stressed. In the present study a sudden increase was registered in HPT serum concentrations, indicating that the sudden weather changes (within a day $16{ }^{\circ} \mathrm{C}$ lower temperature and stress due to chilling) at this time period influenced the animals immune system.

Consistent with Grellner et al. (2002) in the present study the differences in APP between outdoor and indoor animals did not result in significant differences in production levels.

Consistent with Hall et al. (1992) and Grellner et al. (2002), serum HPT concentrations in the present trial were highly correlated with $\mathrm{MH}$ titers in the outdoor pigs. Thus, it seems to be reasonable to suggest that serum HPT is an appropriate indicator for the health status of the pigs. Consistent with Grellner et al. (2002), in the present trial serum concentrations of AGP and HPT did not correlate with changes in serum cortisol concentrations. However, outdoor pigs showed simultaneously a sharp increase in HPT and serum cortisol between ages of 60-90 d during a could weather period. In contrast to outdoor animals, serum cortisol of indoor pigs increased between weaning and $60 \mathrm{~d}$ of age. The earlier increase of serum cortisol in indoor pigs might be explained by crowding and stress in these pigs.

The present results indicate that AGP serum concentrations are negatively correlated with body weight indicating that cellular immune stimulation negatively influences growth of the growing pigs. Further, serum HPT may be a valuable indicator of stress in growing pigs and in combination with higher cortisol concentrations HPT seems to be a more reliable indicator of disease status than HPT or cortisol alone. The present differences in AGP values suggests that they may be useful as biomarkers in the commercial pig production.

Further investigations are needed to determine whether serum cortisol, APPs or a combination of both were reliable predictors of disease status in outdoor producing commercial herds.

\section{Vliv venkovního odchovu na užitkovost prasat, proteiny akutní fáze zánětu a kortizol pod vysokým infekčím tlakem Mycoplasma hyopneumoniae}

Cílem studie bylo vyhodnotit sérové koncentrace proteinů akutní fáze zánětu (APP), haptoglobinu (HPT), $\alpha$ 1-glykoproteinů (AGP) a kortizolu u prasat chovaných ve stáji či venku pod vysokým infekčním tlakem (prevalence) Mycoplasma hyopneumoniae v průběhu času a zjistit zda mají změny APP vliv na užitkovost prasat. Dvě skupiny po 10 prasatech byly od odstavu do porážky odchovávány ve stáji (skupina 1) a 2 skupiny po 10 prasatech stejného věku a zdravotního stavu, byly odchovávány v boudách s výběhem $10 \mathrm{~m}^{2}$ na 1 zvíře (skupina 2). Vzorek séra byl odebrán každému praseti při odstavu (21.den laktace), dále pak 
60., 90., 120. a 150. den života. Byla vyhodnocena data o produkci (průměrný denní přírůstek, procento konverze krmiva), seropozitivita na M. hyopneumoniae, HPT, AGP a kortizol. Prasata chovaná ve stáji měla trvale zvýšenou koncentraci HPT, zatímco u zvírat chovaných venku byl zaznamenán jeden prudký nárůst po období chladného počasí. AGP negativně koreloval s váhou, což ukazuje, že aktivace buněčné imunitní odpovědi negativně ovlivňuje velikost přirůstku a konečnou výkrmovou váhu prasat.

\section{References}

BEREITER, M, YOUNG, TF, JOO, HS, ROS, RF 1990: Evaluation of the ELISA and comparison to the complement fixation test and radial immunodiffusion enzyme assay for detection of antibodies against Mycoplasma hyopneumoniae in swine serum. Vet Microbiol 25: 177-192

BILKEI, G 1996: The management of veterinary extension activities and the practical experiences of pig breeding advisory bureaus in western Europe. Proceeding Pig Days, University of Budapest, Hungary, 3-4, April 1996, pp. 1-3

BILKEI, G, BÖLCSKEI, A, CLAVADETSCHER, E 1995: Der Einfluss verschiedener praxisreifer zootechnischer Massnahmen auf das Auftreten des MMA - Komplexes. Der praktische Tierarzt 1: 42-50

BURGER, W, FENNERT, EM, POHLE, M, WESENMEIER, H 1992: C-Reactive Protein-a characteristic feature of health control in swine. J Vet Med A 39: 635-638

DOCIC, A, BILKEI, G 2001: Effect of vaccination against Mycoplasma hyopneumoniae on health and some production parameter in outdoor and in indoor units. Pig J 47: 23-34

ECKERSALL, PD, SAINI, PK, MCCOMB, C 1996: The acute phase response of acid soluble glycoprotein, alpha 1 -acid glycoproteins, ceruloplasmin, haptoglobin and C-reactive protein in the pig. Vet ImmunolImmunopathol 51: $377-385$

EURELL, TE, BANE, DP, HALL, WF, SCHAEFFER, DJ 1992: Serum haptoglobin concentrations as an indicator of weight gain in pigs. Can J Vet Res 56: 6-9

FRENCH, T 1989: Acute phase proteins. In: French, The Clinical Chemistry of Laboratory Animals. 1st ed. New York, Pergamon Press. Inc. pp. 201-235

GRELLNER, GF, FANGMAN, TJ, CAROLL, JA 2002: Using serology in combination with acute phase proteins and cortisol to determine stress and immune function of early weaned pigs. J Swine Health Prod 10: 199-204

HALL, WF, EUREL, TE, HANSON, RD, HERR, LG 1992: Serum haptoglobin concentration in swine naturally or experimentally infected with Actinobacillus pleuropneumoniae. J Am Vet Med Assoc 201: 1730-1733

HORADAGODA, NU, KNOX, KMG, GIBBS, HA, REID, SWJ, HORADAGODA, A, EDWARDS, SER, ECKERSALL, PD 1999: Acute phase proteins in cattle: discrimination between acute and chronic inflammation. Vet Rec 144: 437-441

ITOH, H, TAMURA, K, IZUMI, M, MOTOI, Y, KIDOGUCHI, K, FUNAYAMA, Y 1993: The influence of age and health status on the serum alpha 1-acid glycoprotein level of conventional and specific pathogen free pigs. Can J Vet Res 57: 74-78

NICOLET, J, PAROZ, P, BRUGGMANN, S 1980: Tween 20 soluble proteins of Mycoplasma hyopneumoniae as antigen for an enzyme linked immunosorbent assay. Res Vet Sci 29: 177-192

SON, DS, HARIYA, S, SHIMODA, M, KOKUE, E 1996: Contributions of alpha 1-acid glycoproteins to plasma binding of some basic antimicrobials in pigs. J Vet Pharm Ther 19: 176-183

SAS, 1990 Statistical Analysis System Institute. Cary, North Carolina. USA. 